\title{
Urgensi Pendidikan Berpikir Kritis Era Merdeka Belajar bagi Peserta Didik
}

\author{
Nanda Alfan Kurniawan ${ }^{1}$, Randi Saputra ${ }^{2}$, Ummu Aiman ${ }^{3}$, Alfaiz $^{4}$, Dita Kurnia Sari ${ }^{5}$ \\ ${ }^{1,2,3}$ Universitas Negeri Malang \\ ${ }^{4}$ STKIP PGRI Sumatera Barat \\ ${ }^{5}$ Universitas Islam Negeri Sunan Ampel Surabaya \\ E-mail: alfan.kurniawan.1801116@student.um.ac.id
}

\begin{abstract}
Abstrak. Pendidikan bagi peserta didik telah memasuki paradigma baru di masa pandemi COVID19 pada lima bulan terakhir. Kebijakan yang ditempuh pemerintah dengan menetapkan merdeka belajar menjadi era baru dalam dunia pendidikan. Peserta didik pada satuan tingkat pendidikan dasar hingga pendidikan tinggi perlu menyesuaikan diri dengan situasi baru dalam proses belajar era merdeka belajar masa kini. Situasi pandemi COVID-19 mengajak pendidikan untuk melakukan aktivitas belajar dan pembelajaran secara tidak langsung melalui media berbasis online dengan memanfaatkan kecanggihan teknologi informasi hasil revolusi industri 4.0. Pendidikan melalui media berbasis online memberikan peluang bagi peserta didik untuk berkembang secara mandiri dengan pembinaan dan bimbingan dari para pendidik dan tenaga kependidikan pada tingkat dasar hingga pendidikan tinggi. Peserta didik membutuhkan bentuk pendidikan yang tepat agar mampu menyesuaikan kondisi pribadi dengan kompetensi yang dibutuhkan dalam pendidikan era merdeka belajar. Pendidikan berpikir kritis menjadi salah satu alternatif bagi peserta didik untuk membekali aspek fisik dan psikis agar mampu menyesuaikan diri dalam pendidikan di era medeka belajar. Tujuan penelitian ini adalah memberikan gambaran deskriptif mengenai pentingnya pendidikan berpikir kritis bagi peserta didik di era merdeka belajar. metode penelitian ini menggunakan studi pustaka. sumber data adalah artikel penelitian dan buku-buku yang relevan dengan tujuan penelitian. Teknik analisis data menggunakan analisis isi (conten analys) dan instrumen penelitian berupa chek list sumber data penelitian yang di butuhkan. hasil penelitian menunjukkan bahwa pendidikan berpikir kritis bagi peserta didik menjadi kebutuhan penting di era merdeka belajar. sehingga pendidik dan tenaga kependidikan perlu menyediakan fasilitas dalam menyediakan pendidikan berpikir kritis bagi peserta didik.
\end{abstract}

Kata Kunci: berpikir kritis, era merdeka belajar

\begin{abstract}
Education for students has entered a new paradigm during the COVID -19 pandemic in the last five months. The policy pursued by the government by establishing free learning became a new era in the world of education. Learners at the level of basic education to tertiary education need to adjust to the new situation in the learning process of the current era of independent learning. The co-19 pandemic situation invites education to conduct learning and learning activities indirectly through online-based media by utilizing the sophistication of information technology as a result of the industrial revolution 4.0. Education through online-based media provides opportunities for students to develop independently with coaching and guidance from educators and education staff at the elementary to the tertiary level. Students need the right form of education in order to be able to adjust personal conditions with the competencies needed in education of the independent learning era. Critical thinking education is one alternative for students to equip physical and psychological aspects to be able to adjust to education in the era of learning. The purpose of this study is to provide a descriptive picture of the importance of critical thinking education for students in the independent learning era. This research method uses literature study. Data sources are research articles and books relevant to the purpose of the study. Data analysis techniques using content analysis (content analysis) and research instruments in the form of a check list of research data sources that are needed. The results showed that critical thinking education for students
\end{abstract}


became an important requirement in the era of independent learning. So that educators and education personnel need to provide facilities in providing critical thinking education for students.

Keywords: Critical Thinking, Merdeka Belajar Era

\section{PENDAHULUAN}

Pendidikan Indonesia di awal tahun 2020 mula memasuki situasi baru akibat dampak pandemi covid-19 yang telah mengganggu aktivitas proses belajar dan pembelajaran bagi peserta didik. Kondisi ini berlaku mulai dari satuan pendidikan tingkat dasar hingga pendidikan tinggi, bahkan bagi pendidikan pra sekolah juga terkena dampak pandemi covid-19 (Nicola et al., 2020). Situasi tersebut mengundang berbagai kebijakan dalam upaya menghadapi dampak pandemi covid-19 yang semakin parah. Tercatat hampir 107 Negara di dunia akhirnya memutuskan ketetapan untuk menutup sekolah dalam masa yang belum ditentukan (Viner et al., 2020).

Penutupan sekolah memberikan peluang dan tantangan bagi pendidik dalam menyelenggarakan pendidikan bagi peserta didik (Lee, 2020; Toquero, 2020). Berbagai upaya ditempuh agar peserta didik tetap mendapatkan layanan pendidikan yang berkualitas dan profesional. peluang yang muncul yakni berpotensi mendorong terciptanya lingkungan pendidikan yang revolusioner (Rose, 2020), sedangkan tantangan yang hadir yakni pemenuhan kompetensi bagi pendidik, tenaga kependidikan dan peserta didik untuk mampu menyesuaikan diri dengan sistem pendidikan revolusioner tersebut.

Pandemi covid-19 menghasilkan problematika dalam setiap tingkat satuan pendidikan (Bao, 2020; Chick et al., 2020). Salah satu upaya dalam pendidikan yang di tempuh untuk menyediakan layanan pendidikan bagi peserta didik adalah melakukan pembelajaran melalui metode daring (dalam jaringan) dengan menggunakan perangkat teknologi informasi berbasis online. Namun usaha ini juga masih menimbulkan problematika bagi terwujudnya pendidikan berkualitas masa pandemi. Kondisi itu terjadi akibat kesulitan yang dialami oleh penyelenggaran pendidikan untuk melakukan moda daring bahkan di beberapa negara industri besar (Basilaia \& Kvavadze, 2020; Cao et al., 2020; Esposito \& Principi, 2020).

Kebijakan merdeka belajar yang di tetapkan oleh Menteri Pendidikan menjadi usaha strategis yang siap diterapkan oleh pemerintah dalam menghadapi dampak pandemi covid-19 bagi peserta didik (Abidah et al., 2020). Kebikajkan merdeka belajar menawarkan budaya belajar yang mandiri dengan memanfaatkan teknologi informasi sesuai kebutuhan hidup (Arifin \& Muslim, 2020), Tidak hanya dengan adanya kebijakan merdeka belajar bisa melahirkan potensi agentik yang kuat pada diri siswa secara intensional, forethought, realisasi perilaku dan refleksi belajar (Alfaiz, et, al, 2019). Kebijakan ini akhirnya diterjemahkan dalam bentuk pola pembelajaran berbasis online atau dikenal dengan istilah moda daring (dalam jaringan) oleh penyelenggaran pendidikan di sekolah 
seperti yang telah di singgung pada paragraf sebelumya. Menurut data tercatat sebanyak 45,5 juta siswa sekolah dan 3,1 juta guru melakukan pengajaran dan pembelajaran online (Almanthari et al., 2020).

Penyelenggaraan pendidikan tidak dapat dipisahkan dengan model strategi pelaksanaan proses belajar pembelajaran bagi peserta didik. Pendekatan strategi yang inovatif diakui sebagai bentuk kelas terbaik bagi peserta didik (Hwang et al., 2015). Namun, aktivitas belajar dan pembelajaran di era merdeka belajar tidak sepenuhnya dipengaruhi oleh perangkat strategi yang inovatif, tetapi juga melainkan dengan pelayanan konseling yang bersifat spiritual (Saputra, R, et, al, 2019). Selama isi materi dan tujuan yang di rencanakan tepat maka tujuan pembelajaran akan berpotensi dapat tercapai secara optimal (Kim et al., 2014) dengan tetap berdasarkan pada prinsipprinsip belajar.

\section{METODE}

Penelitian ini menggunakan pendekatan kualitatif dengan metode studi pustaka (library research). Studi pustaka merupakan sebuah metode dalam mengkaji sumber-sumber pustaka untuk memperoleh data penelitian.data penelitian adalah arikel penelitian dan buku-buku yang relevan dengan tujuan penelitian. Sumber data diperoleh melalui media online dengan mengakses jurnal terindeks nasional dan internasional, sedangkan sumber data media cetak diperoleh melalui bukubuku. Teknik analisis data menggunakan analisi isi (conten analys). Instrumen penelitian mengguakan daftar chek list inventaris sumber sumber pustaka berdasarkan tahun terbitan, isi materi dan variabel penelitian.

\section{PEMBAHASAN}

Pendidik di tiap tingkat satuan pendidikan memiliki kesempatan mengajak peserta didik untuk menjelajahi dimensi ilmu pengetahuan secara mendalam membantu mereka mengklarifikasi nilai keliru yang dipahami selama ini (Bergmann \& Sams, 2012). Pendidikan di era merdeka belajar memberikan banyak peluang bagi penyelenggaraan pendidikan berpikir kritis bagi peserta didik. Terdapat beberapa bentuk strategi pendidikan yang mengarahkan berpikir kritis (Hwang et al., 2015) seperti problem based learning (Martyn et al., 2014; Masek \& Yamin, 2011), project based learning (Anazifa \& Djukri, 2017; Bell, 2010), discovery learning (Putri et al., 2020; Yerimadesi et al., 2019), dan blended learning (Jou et al., 2016).

Pendidikan berpikir kritis menjadi proyeksi kebutuhan di abad 21 dan menjadi kebutuhan yang diterima secara luas (Hitchcock, 2018). Terlebih dengan situasi pembelajaran mandiri di era 
merdeka belajar semakin memperkokoh kebutuhan peserta didik akan pendidikan berpikir kritis. Selain memberikan dukungan dalam proses pembelajaran, pendidikan berpikir kritis juga membantu peserta didik untuk menggali dan melatihkan potensi-potensi lain dalam dirinya yang dapat di gunakan untuk mencapai aktualisasi diri dalam aspek pribadi, sosial, belajar dan karir.

Berpikir kritis bagi peserta didik penting dimiliki pada setiap tingkat satuan pendidikan (Hidayah, 2015; Suarniati et al., 2019, 2018). Dalam Pendidikan era merdeka belajar mendorong peserta didik untuk mengelola materi belajar secara mandiri, oleh karena itu peran konselor sangat dibutuhkan untuk membentuk kemadnirian belajar (Ramdani, et, al, 2020), dan juga hal ini menyebabkan keterbatasan tatap muka dengan guru mata pelajaran. Pendidikan berpikir kritis menurut Presiden Barak Obama dalam State of the Union Address pada tahun 2014 menetapkan pemikiran kritis sebagai salah satu dari enam tujuan dasar pendidikan (Ennis, 2018). Aktivitas pendidikan berpikir kritis tersebut tentu perlu didukung dengan kemampuan kognisi yang baik oleh setiap peserta didik.

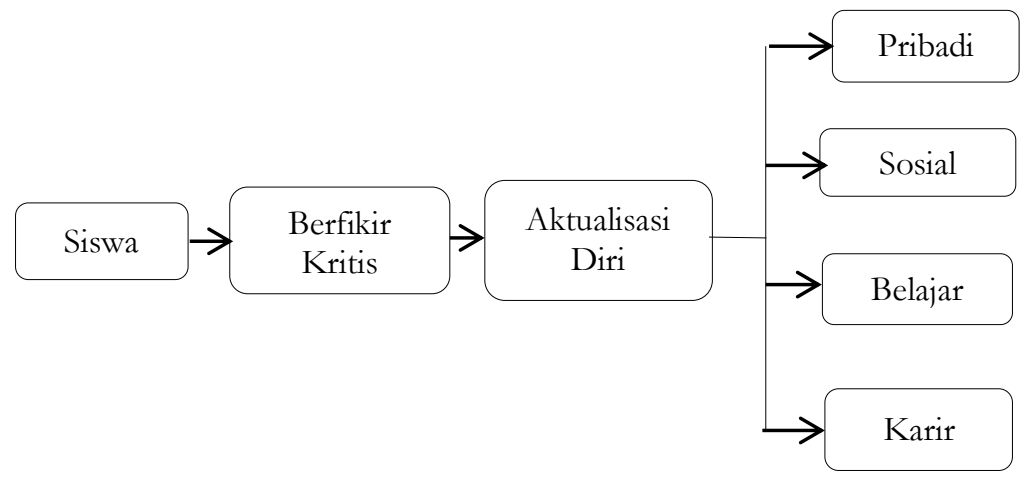

\section{Gambar 1. Aktivitas Pendidikan Berpikir Kritis}

\section{PENUTUP}

Pendidikan menjadi kebutuhan mendasar bagi terbentuknya suatu peradaban. Era merdeka belajar membuka peluang dan tantangan bagi pendidikan dalam melahirkan peradaban baru. Peserta didik di tiap satuan tingkat pendidikan diharapkan memiliki kemampuan yang unggul untuk menyesuaikan diri dengan perubahan peradaban. Pendidikan berpikir kritis akhirnya menjadi sebuah alternatif bagi pemerintah dan penyelenggara layanan pendidikan untuk memfasilitasi perkembangan kemampuan berpikir kritis bagi peserta didik. Selain mempersiapkan peserta didik, urgensi pendidikan berpikir kritis dimaksudkan agar peserta didik dapat menggali lebih banyak potensi dalam diri pribadinya sebagai modal dalam menghadapi perkembangan peradaban pada situasi berbeda di masa mendatang. 


\section{REFERENSI}

Abidah, A., Hidaayatullaah, H. N., Simamora, R. M., Fehabutar, D., \& Mutakinati, L. (2020). The Impact of Covid-19 to Indonesian Education and Its Relation to the Philosophy of "Merdeka Belajar." Studies in Philosophy of Science and Education, 1(1), 38-49.

Almanthari, A., Maulina, S., \& Bruce, S. (2020). Secondary School Mathematics Teachers' Views on E-learning Implementation Barriers during the COVID-19 Pandemic: The Case of Indonesia. Eurasia Journal of Mathematics, Science and Technology Education, 16(7), em1860.

Alfaiz, A, Yandri, H., Yuzarion, Y, Lestari, L.P.S, \& Heriyani. E., (2019). Persepsi Agentik Individu untuk Mencapai Prestasi Pribadi dalam Aktivitas Karir : Riset Pendahuluan. Psychocentrum Review, Vol. 1 No. 2, p. 85-95. https://doi.org/10.30998/pcr.1276. https://journal.unindra.ac.id/index.php/pcr/article/view/76.

Alfaiz, Hidayah, N, Hambali, IM, \& Radjah, C.L. (2019). Human Agency as a Self-Cognition of Human Autonomous Learning: A Synthesized Practical of Agentic Approach. Journal of Social

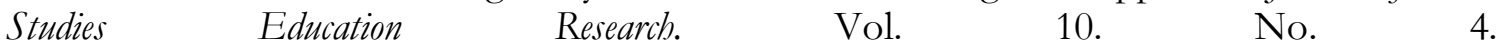
https://www.jsser.org/index.php/jsser/article/view/1370.

Anazifa, R. D., \& Djukri, D. (2017). Project-Based Learning and Problem-Based Learning: Are They Effective to Improve Student's Thinking Skills? Jurnal Pendidikan IPA Indonesia, 6(2), 346-355.

Arifin, S., \& Muslim, M. O. H. (2020). Tantangan Implementasi Kebijakan "Merdeka Belajar, Kampus Merdeka" pada Perguruan Tinggi Islam Swasta di Indonesia. JURNAL PENDIDIKAN ISLAM AL-ILMI, 3(1).

Bao, W. (2020). COVID-19 and online teaching in higher education: A case study of Peking University. Human Behavior and Emerging Technologies, 2(2), 113-115.

Basilaia, G., \& Kvavadze, D. (2020). Transition to online education in schools during a SARS-CoV2 coronavirus (COVID-19) pandemic in Georgia. Pedagogical Research, 5(4), 1-9.

Bell, S. (2010). Project-based learning for the 21st century: Skills for the future. The Clearing House, 83(2), 39-43.

Bergmann, J., \& Sams, A. (2012). Flip your classroom: Reach every student in every class every day. International society for technology in education.

Cao, W., Fang, Z., Hou, G., Han, M., Xu, X., Dong, J., \& Zheng, J. (2020). The psychological impact of the COVID-19 epidemic on college students in China. Psychiatry Research, 112934.

Chick, R. C., Clifton, G. T., Peace, K. M., Propper, B. W., Hale, D. F., Alseidi, A. A., \& Vreeland, T. J. (2020). Using technology to maintain the education of residents during the COVID-19 pandemic. Journal of Surgical Education.

Ennis, R. H. (2018). Critical thinking across the curriculum: A vision. Topoi, 37(1), 165-184.

Esposito, S., \& Principi, N. (2020). School closure during the coronavirus disease 2019 (COVID19) pandemic: an effective intervention at the global level? JAMA Pediatrics.

Hidayah, N. (2015). Mengasah Keterampilan Berpikir Kritis dan Kreatif. Makalah Dalam Prosiding Seminar Nasional Bimbingan Dan Konseling Di Surabaya, Kerjasama Pengurus Daerah ABKIN [Asosiasi Bimbingan Dan Konseling Indonesia] Jawa Timur Dan Universitas PGRI [Persatuan Guru Republik Indonesia] Adibuana Surabaya.

Hwang, G.-J., Lai, C.-L., \& Wang, S.-Y. (2015). Seamless flipped learning: a mobile technologyenhanced flipped classroom with effective learning strategies. Journal of Computers in Education, 2(4), 449-473.

Jou, M., Lin, Y.-T., \& Wu, D.-W. (2016). Effect of a blended learning environment on student critical thinking and knowledge transformation. Interactive Learning Environments, 24(6), 11311147.

Kim, M. K., Kim, S. M., Khera, O., \& Getman, J. (2014). The experience of three flipped 
classrooms in an urban university: an exploration of design principles. The Internet and Higher Education, 22, 37-50.

Lee, J. (2020). Mental health effects of school closures during COVID-19. The Lancet Child \& Adolescent Health, 4(6), 421.

Martyn, J., Terwijn, R., Kek, M. Y. C. A., \& Huijser, H. (2014). Exploring the relationships between teaching, approaches to learning and critical thinking in a problem-based learning foundation nursing course. Nurse Education Today, 34(5), 829-835.

Masek, A., \& Yamin, S. (2011). The effect of problem based learning on critical thinking ability: a theoretical and empirical review. International Review of Social Sciences and Humanities, 2(1), 215221.

Nicola, M., Alsafi, Z., Sohrabi, C., Kerwan, A., Al-Jabir, A., Iosifidis, C., Agha, M., \& Agha, R. (2020). The socio-economic implications of the coronavirus pandemic (COVID-19): A review. International Journal of Surgery (London, England), 78, 185.

Putri, A., Roza, Y., \& Maimunah, M. (2020). Development of learning tools with the discovery learning model to improve the critical thinking ability of mathematics. Journal of Educational Sciences, 4(1), 83-92.

Ramdani, R, Rofiqah, T, Khairat, I, Saragi, M.P.D, Saputra, R. (2020). The Role of School Counselors to Helping Student in Puberty Through The Collaborative Paradigm. ENLIGHTEN: Jurnal Bimbingan Konseling Islam. Vol. 3. No 1. https://journal.iainlangsa.ac.id/index.php/enlighten/article/view/1528

Rose, S. (2020). Medical student education in the time of COVID-19. Jama.

Saputra, R, Hasrul, Ammamiarihta, Handayani, P.G, (2019). Konseling Religius Berbasis Rasional Emotif Behavior Terapi (REBT) untuk Meningkatkan Kesadaran Spiritual Keagamaan Siswa SMA. Jurnal KOPASTA. Vol. https://www.journal.unrika.ac.id/index.php/kopastajournal/article/view/2129.

Suarniati, N. W., Ardhana, I. W., Hidayah, N., \& Handarini, D. M. (2019). The Difference between the effects of problem-based learning strategy and conventional strategy on vocational school students' critical thinking skills in civic education. International Journal of Learning, Teaching and Educational Research, 18(8).

Suarniati, N. W., Hidayah, N., \& Handarini, M. D. (2018). The development of learning tools to improve students' critical thinking skills in vocational high school. IOP Conference Series: Earth and Environmental Science, 175(1), 12095.

Toquero, C. M. (2020). Challenges and opportunities for higher education amid the COVID-19 pandemic: The Philippine context. Pedagogical Research, 5(4).

Viner, R. M., Russell, S. J., Croker, H., Packer, J., Ward, J., Stansfield, C., Mytton, O., Bonell, C., \& Booy, R. (2020). School closure and management practices during coronavirus outbreaks including COVID-19: a rapid systematic review. The Lancet Child \& Adolescent Health.

Yerimadesi, Y., Bayharti, B., Azizah, A., Lufri, L., Andromeda, A., \& Guspatni, G. (2019). Effectiveness of acid-base modules based on guided discovery learning for increasing critical thinking skills and learning outcomes of senior high school student. Journal of Physics: Conference Series, $1185(1), 12151$. 